\title{
Influencing panic : experimental and clinical studies into determinants of panic severity
}

Citation for published version (APA):

Knuts, I. J. E. (2015). Influencing panic : experimental and clinical studies into determinants of panic severity. [Doctoral Thesis, Maastricht University]. Datawyse. https://doi.org/10.26481/dis.20150527ik

Document status and date:

Published: 01/01/2015

DOI:

10.26481/dis.20150527ik

Document Version:

Publisher's PDF, also known as Version of record

\section{Please check the document version of this publication:}

- A submitted manuscript is the version of the article upon submission and before peer-review. There can be important differences between the submitted version and the official published version of record.

People interested in the research are advised to contact the author for the final version of the publication, or visit the DOI to the publisher's website.

- The final author version and the galley proof are versions of the publication after peer review.

- The final published version features the final layout of the paper including the volume, issue and page numbers.

Link to publication

\footnotetext{
General rights rights.

- You may freely distribute the URL identifying the publication in the public portal. please follow below link for the End User Agreement:

www.umlib.nl/taverne-license

Take down policy

If you believe that this document breaches copyright please contact us at:

repository@maastrichtuniversity.nl

providing details and we will investigate your claim.
}

Copyright and moral rights for the publications made accessible in the public portal are retained by the authors and/or other copyright owners and it is a condition of accessing publications that users recognise and abide by the legal requirements associated with these

- Users may download and print one copy of any publication from the public portal for the purpose of private study or research.

- You may not further distribute the material or use it for any profit-making activity or commercial gain

If the publication is distributed under the terms of Article $25 \mathrm{fa}$ of the Dutch Copyright Act, indicated by the "Taverne" license above, 
Stellingen behorend bij het proefschrift

\section{Influencing panic}

\section{Experimental and clinical studies into determinants of panic severity}

\section{Inge J. E. Knuts}

woensdag 27 mei 2015 om 16.00 uur

1. Smoking leads to panic, panic not to smoking

2. The outcome of a 1-week CBT program for agoraphobia is as successful as the classical ' 12 weeks' CBT program.

3. Depression frequently accompanies PDA and does not affect treatment, focusing on PDA, outcome negatively.

4. The efficacy of exposure-based behavior therapy depends on the 5-HTTLPR polymorphism

5. It is impossible to improve what cannot be measured or to measure what hasn't been defined. Take for example the topic healthcare quality; everyone wants quality, but everyone's keeping score differently'. (Price Waterhouse Coopers, Health Research Institute - Keeping score- 2007)

6. The largest part of what we call 'personality' is determined by how we've opted to defend ourselves against anxiety and sadness (Alain de Botton)

7. In de angst wordt de mens zich bewust van zijn vrijheid. (Jean-Paul Sartre)

8. To provide cost-effective treatment, further exploration of strategies to shorten the duration of therapy of PD is necessary.

9. There's no limit to how complicated things can get, on account of one thing always leading to another." (E.B. White)

10. It is costly wisdom that is bought by experience (Robert Ascham)

11. The moment in between what you once were, and who you are now becoming, is where the dance of life really takes place (B.De Angelis) 